\title{
Web Design and Company Image
}

\author{
Joze Kuzic \\ Monash University, Melbourne, \\ Australia
}

George Giannatos

AEMO, Melbourne, Australia

\author{
Joze.Kuzic@infotech.monash.edu.au George.Giannatos@aemo.com.au \\ Tanja Vignjevic \\ Monash University, Melbourne, Australia \\ tvig1@student.monash.edu
}

\begin{abstract}
Research reported in this paper looks at the interrelationship between web site design and company image. The research has found that visiting and evaluating company's web sites can change customers' perceptions about the image of that company. The paper also shows the influence of specific website attributes in portraying the image of the companies. Some web site features such as navigability, content, and first impressions, influence a company's image more than others. Additionally, the research shows gender differences in regard to the interrelationship between the web site features and company image.
\end{abstract}

Keywords: Web site design, web site features, company image.

\section{Introduction}

Anecdotal evidence suggests that many companies are using web sites, together with the Internet, in their efforts to satisfy customers. This is supported by the fact that 'Internet income for businesses in Australia has increased from $\$ 5.1$ billion in 1999-2000 to $\$ 33$ billion in 2003-2004, representing an increase of 55\% over a period of 4 years' (NOIE, 2003). Additionally, the ability of web site features to influence company image is not only playing a significant role in how these companies cater to their customers' needs, but is a reflection of how important it is to have a website that is easy to navigate, has rich content, and is capable of keeping customers longer on the site.

As time is of the essence it is vitally important for the web site's visitors to complete the task efficiently, to obtain information or conduct a transaction in a timely manner. This has been emphasized time and again by Huizingh and Hoekstra (2002), who are of the opinion that the ease of

Material published as part of this publication, either on-line or in print, is copyrighted by the Informing Science Institute. Permission to make digital or paper copy of part or all of these works for personal or classroom use is granted without fee provided that the copies are not made or distributed for profit or commercial advantage AND that copies 1) bear this notice in full and 2) give the full citation on the first page. It is permissible to abstract these works so long as credit is given. To copy in all other cases or to republish or to post on a server or to redistribute to lists requires specific permission and payment of a fee. Contact 0HPublisher@InformingScience.org to request redistribution permission. navigation has a large impact on usability and perceived ability of the web sites. This allows companies to attract the so-called "right" customers, instead of being focused on attracting large numbers of customers.

Furthermore, the design of the web site that is capable of helping people to move through information efficiently by providing appropriate links is adding to 
the company's ability to increase revenue and profit (Block, 1999; Vredenburg, 2003). Some researchers, such as Chatterjee, Grewal, and Sambamurthy (2002), believe that businesses are starting to focus on facilitating more effective transformations to the web-enabled business environments, as well as on the improvement of the user experiences (Vredenburg, 2003). Research conducted by Rose and Straub (2001) found that there is an influence of download time on consumer attitudes toward web retailers.

First impressions are one of the most important features of company web site's (McKnight \& Charles, 2007). Companies are aware of the importance of first impressions, which are capable of forming consumer mind-set and future implications for use of the web site (Giffin, 1967). Tsalikis, Ortiz-Buonafina and LaTour (1992) also agree that first impressions can be powerful indicators about web sites credibility, as people tend to rely on these. In addition, it is important for companies to understand that the easier the web site use, the better it is received by clients (Melius \& Mongezi, 2004).

\section{Literature Review}

Image can be described as a mental representation; idea; conception (Dictionary.com). In another words, the image is a form of cognition. Company image, on the other hand, is 'the immediate mental picture that audiences have of an organization' (Gray \& Balmer, 1998). Thus, a company image is an accepted view of what a company stands for. A company image can be roughly divided into three categories: interior and exterior image, physical and virtual image, and internal and external image (NOIE, 2003). A good company image will help a company build close relationships with its clients while a bad one is likely to keep the clients away. Indeed, a good company image can generate many advantages for the company. It is almost impossible to overstate the significance of a good image to a company. In this case, 'a good image is virtually a valuable asset to an organization' (Dowling, 1994).

Company image is definitely designed to be appealing to its clients, so that 'it can spark an interest among consumers, create share of mind, generate brand quality, and thus facilitate sales' (Prtz, 2008). Thus, it is important to develop an effective website that can support a good company image and reputation. Ultimately, the survival of the company could, to a certain extent, be attributed to its ability to attain and retain a good image in today's sensitive business world (Gray \& Balmer, 1998).

In the electronic commerce environment nowadays it is almost expected that customer quality perceptions of web sites play a vital role in a company's success (Zhang, vonDran, 2002). A well designed web site can provide a company with an additional benefit; a competitive advantage (Yang et al., 2003). Furthermore, some customers do change their attitudes towards the company after visiting their web sites, so it does influence the image as well. A body of research that focuses on usability of the web site suggests that a dependent relationship exist between the quality of the web site and its usability (Kim, Shaw, \& Schnider, 2003). Additionally, from the business point of view, according to Block (1999), the feature that most helps companies create profits is the design of the web site, where appropriate links can help people move through information in a natural and effective way. Furthermore, established companies with well known brands have realised that one of the most important features of their web sites is their URL. The usability of a web site, is another important website feature, has an impact on how favourably a user views a vendor, and it could be concluded this has a direct impact on company image (Araujo \& Araujo, 2003). Additionally, the higher the users rated the ease-of-use of the site, the greater the credibility of the site in the users' eyes. Navigation is a major activity performed by users interacting with web sites. 
Navigation is an important component of how quickly tasks can be completed and the literature suggests that users' responses to a website will be determined more by how quickly they were able to complete the task or obtain the information they required from that site rather than how exciting a site is (Eighmey \& McCord, 1998; Gefen \& Straub, 2000). The literature proposes a number of reasons why navigation is an important consideration in web site design includes: The credibility of a company's website can be affected by a poor navigation experience by a user (Araujo \& Araujo, 2003); users spend more time at the site (Zhang \& von Dran, 2000); Users will discontinue use of a site if it becomes difficult to navigate or too complex or too many clicks are needed to reach the required information(Shim, Shin, \& Nottingham, 2002); Users will be more likely to make a transaction if the design, including navigation, is effective (Aladwani, 2002; Tilson, Dong, Martin, \& Kieke, 1998); Users will make more use of the site and more information will be distributed, if it is easily navigated (Silker \& Gurak, 1996). Thus, if you want to satisfy your customers by having a good navigational site then it should "have a strong sense of structure and navigation support in the site so that users know where they are, where they have been, and where they can go"(Nielsen, 1999) .

Another feature that is also capable of increasing sales and therefore boosting company's revenue and profit is the ease of use of the web site (Vredenburg, 2003). A body of research that focuses on usability of the web site suggests that a dependent relationship exist between the quality of the web site and its usability (Kim et al., 2003). In addition, Yang et al. (2003) are of the opinion that for established companies with well known brands one of the most important features of their web sites is their URL. From the electronic commerce perspective, web sites represent corporations' primary interface with the customers, thus the quality of the web sites is critical for a successful electronic commerce strategy that is capable of bringing about benefits. Major roles in that strategy are played by web site attractiveness including systematic structure and navigation (Kim et al., 2003). A review of literature for this research has revealed the influence of certain web site features such as download time, first impressions and web site design (Otto, Najdawi, \& Wagner, 2003; Rose \& Straub, 2001; Schenkman \& Johnsson, 2000) on "switching" behavior of the users and consequently on company/brand image. The literature has also revealed some of the benefits that companies might be able to achieve (such as competitive advantage, business effectiveness, customer loyalty, and achievement of real integration in the organization, etc.) by focusing their attention on improving various web site features (Block, 1999; Sternberg, 2002; Vredenburg, 2003; Yang, et al., 2003).

\section{Research Methodologies}

The aim of this research is to investigate if the perceptions of users and potential customers of a company might be influenced by the company's web site, as well as to explore the relationships between a company's web site's features and the company's image. The research was guided by the following questions:

- Does visiting and evaluating web sites change visitors' perceptions about a company's image?

- What are the most important features on a web site?

- What is the relationship, if any, between the particular features of the web site and the image of the company?

The literature suggests that it is possible to evaluate web sites using a variety of evaluation categories. However, there is very little evidence concerning a consensus among researchers about appropriate criteria for that evaluation (Kim et al., 2003). For this project we adapted the Web 
Effectiveness Review tool developed at Trinity College, Dublin by Dan Remenyi (http://www.mcil.co.uk/).

This research was accomplished in three phases. In the first phase a group of 60 employees, who have been using Internet at their work place on a daily basis, in an Australian company were given a task to evaluate a web site using the MCIL (Management Centre International Limited) website effectiveness review tool, available on (http://www.mcil.co.uk/). In the second phase collated data were analyzed using qualitative and quantitative techniques. Findings and conclusions were drawn in the third phase.

Firstly, the participants were asked to record their opinion about the image of the companies whose web sites they were evaluating on a scale from 1 to 10 with 1 indicating a bad image and 10 indicating a very good image. Secondly, participants were introduced to the MCIL tool and asked to indicate their opinions about the importance of particular features on web sites regarding the criteria for evaluation called.

Participants were asked to record their answers on an ordinal Likert scale, ranging from 1 to 10 with 1 indicating low level of importance to 10 indicating high level of importance. Likert and similar scales have been used by many researchers in information systems and other fields, such as Lawrence and Low (1993), Blackwell (1995), Gearson and Gearson (1995), Rose and Straub (2001), and Kuzic and Billington (2003). Finally, the participants were asked to express their opinion about the image of the companies, after they evaluated their web sites, again on a scale from 1 to 10: one indicating a bad image and 10 indicating a very good image. Since the acquired data were measured on an ordinal scale, it was appropriate to perform non-parametric statistical tests (Siegel, 1988).

In accordance with the collated data, appropriate statistical analyses such as Rank order, the Sign Test, and Correlation Analysis were conducted. The Sign Test was conducted to establish whether the participants changed their opinions about company's image after evaluating their web sites. The Sign test is often used on occasions as "pre-test post-test" (Cramer, 1998) and "before and after study" (Siegel, 1988). Similar research with pre-adoption and post adoption examination had been undertaken in the information systems fields (Karahanna, Straub, \& Cherveny, 1999; Kuzic, Fisher, \& Scollary, 2002).

\section{Data Analysis}

Correlation analysis was conducted to find if a relationship between the particular features of the web sites and the image of the companies existed. The results of the Sign test are presented in Table 1 .

Table 1. Sign Test for image in the entire population.

\begin{tabular}{lll}
\hline $\begin{array}{l}\text { Pre-evaluation } \\
\text { (Mean) }\end{array}$ & $\begin{array}{l}\text { Post-evaluation } \\
\text { (Mean) }\end{array}$ & $\begin{array}{l}\text { Sign Test } \\
\text { P-value }\end{array}$ \\
\hline 7.1303 & 7.5170 & .211
\end{tabular}

The results of the Sign test suggest that differences between pre-evaluation and post-evaluation existed. According to P-value of the sign test performed, however, the difference was not statistically significant $(>.05)$. Thus the results of the Sign test indicate overall, in the entire population, features of the web sites did not have a significant impact on the image of companies whose web sites were evaluated. 
In order to find out whether the web site features had an impact on company's image among different gender groups of participants, the Sign Test was performed using the data collated in two separate groups, namely Male and Female. The results of the Sign Test in these two groups are presented in Table 2.

Table 2. Sign Test for image in the male and female population

\begin{tabular}{llllll}
\hline \multicolumn{3}{c}{ Male } & \multicolumn{3}{c}{ Female } \\
\hline Pre-ev & Post-ev & S Test & Pre-ev & Post-ev & S Test \\
7.1664 & 7.5631 & .472 & 7.5004 & 7.9877 & .017
\end{tabular}

The results of the Sign test in male and female populations suggest that the differences in image between pre-evaluation and post-evaluation existed. However, according to P-values of the sign test, the difference was statistically significant only in the female group (shaded). Thus only female participants significantly changed their attitudes towards the companies' image after the evaluation of their web site.

In order to establish the rank of the importance of web site features in the entire sample of participants, their medians and means were computed. A table containing a descending order of features of web sites is presented in Table 3 .

Table 3. Rank order for top 5 web site features in the entire population

\begin{tabular}{ll}
\hline $\begin{array}{l}\text { Ran } \\
\mathrm{k}\end{array}$ & Features \\
\hline 1 & Ease of navigation \\
2 & Intuitive URL \\
3 & Contact details \\
4 & Freebees \\
5 & Useful information
\end{tabular}

To find out if there is a difference in ranking the importance of web site features in the two groups, and those in the entire sample, the same computations were undertaken. The rank orders of top five features in male and female populations are presented in the Tables 4 and 5.

Table 4. Rank order for top 5 web site features in the male population

\begin{tabular}{ll}
\hline $\begin{array}{l}\text { Ran } \\
\mathrm{k}\end{array}$ & Features \\
\hline 1 & Mission statement \\
2 & Freebees \\
3 & Ease of navigation \\
4 & Intuitive URL \\
5 & Contact details
\end{tabular}


Table 5. Rank order for top 5 web site features in the female population

\begin{tabular}{ll}
\hline Rank & Features \\
\hline 1 & Useful information \\
2 & Access for people with disabilities \\
3 & Contact details \\
4 & Ease of navigation \\
5 & First impressions
\end{tabular}

To establish whether the relationship between the companies' image and particular features of their web sites exist, a correlation analysis was conducted. The correlation analysis indicated that a number of variables were correlated and statistically significant. The top five correlations, according to their strength, in the whole, male and female populations are presented in Tables 6, 7, and 8 .

Table 6. Top five correlations for the whole population

\begin{tabular}{llll}
\hline & Web site Features & $\begin{array}{l}\text { Strength of } \\
\text { Correlations }\end{array}$ & $\begin{array}{l}\text { Level of Sig- } \\
\text { nificance }\end{array}$ \\
\hline Image & Intuitive URL & 0.866 & 0.000 \\
Image & Ease of navigation & 0.854 & 0.000 \\
Image & First impressions & 0.811 & 0.000 \\
Image & Freebees & 0.735 & 0.000 \\
Image & Useful information & 0.700 & 0.000
\end{tabular}

Table 7. Top five correlations for the male population

\begin{tabular}{llll}
\hline & Web site Features & $\begin{array}{l}\text { Strength of } \\
\text { Correlations }\end{array}$ & $\begin{array}{l}\text { Level of Sig- } \\
\text { nificance }\end{array}$ \\
\hline Image & Mission statement & 0.811 & 0.000 \\
Image & Useful information & 0.800 & 0.000 \\
Image & Having Unique Selling & & \\
& Point (USP) & 0.761 & 0.000 \\
Image & Intuitive URL & 0.731 & 0.000 \\
Image & Ease of navigation & 0.697 & 0.000
\end{tabular}


Table 8. Top five correlations for the female population

\begin{tabular}{llll}
\hline & Web site Features & $\begin{array}{l}\text { Strength of } \\
\text { Correlations }\end{array}$ & $\begin{array}{l}\text { Level of Sig- } \\
\text { nificance }\end{array}$ \\
\hline Image & $\begin{array}{l}\text { Home page on one } \\
\text { screen }\end{array}$ & 0.902 & 0.000 \\
Image & Useful information & 0.886 & 0.000 \\
Image & $\begin{array}{l}\text { Contact details on the } \\
\text { page }\end{array}$ & 0.833 & 0.000 \\
Image & $\begin{array}{l}\text { Access for people with } \\
\text { disabilities }\end{array}$ & 0.810 & 0.000 \\
Image & Ease of navigation & 0.788 & 0.000
\end{tabular}

The level of significance $(<.05)$, as an indicator of the strength of the correlation, indicates that all these correlations were statistically significant, thus influencing the image of the company.

\section{Findings and Discussion}

The analyses determined that there are differences between the whole population and the two groups of participants within the population regarding changing perceptions of the company image. Additionally, there are differences in male and female population regarding the importance of the web site features, and their influence on company image. For the whole population, visiting and evaluating particular web site did not change their perception of the company image, indicating that the perception of the company image was very much established. The same conclusion could be drawn for the male population. On the other hand, analysis of the female population indicated a change in their perception about company image after visiting and evaluating the web site. This shows that this group has changed their opinion, suggesting that the features of the web site have influenced their perception about company image significantly.

As for the importance or ranking of particular web site features, the analyses show that the whole populations, as well as the two groups within the population have similar views about the importance of web site features. The eight web site features represented in the top five for all three populations include: ease of navigation, intuitive URL, contact details, freebees, useful information, mission statement, access for people with disabilities and first impressions.

Finally, there are similarities and differences in three populations regarding the relationship between the image of the company and web site features. In all three populations ease of navigation, and useful information showed a significant relationship with the image of the company. On the other hand in the male population other features influencing the image included mission statement, USP, and intuitive URL. As far as the female population was concerned important features included access for people with disabilities, contact details, and a home page that fits on a single screen.

\section{Conclusions}

The paper investigated whether visiting and evaluating web sites by potential customers or visitors has any impact on company image held by those visitors. The results indicate that female participation, in some cases, changes their perception of a company image after being exposed to that company web site, while males do not. 
The research has also indicated that male and female populations have different views about the importance of web site features and their influence on the company image. Even though the whole population and both groups within the population have ranked the web site features similarly, the differences exist in their importance for the two groups. The male group emphasized the importance of a mission statement, while the female group has paid more attention to Access for people with disabilities and first impressions.

Finally, this research has found that some web site features are more capable of influencing the image of the company. These include access for people with disabilities, contact details on the page, home page on a single screen, mission statement, USP and intuitive URL. The limitation of this paper is in the fact that we had only 60 participants in the research, thus the findings cannot be generalized. Despite these limitations, the paper has provided us with an insight of how the web site features can influence image of the company, and further research will be conducted on a larger scale and hopefully would be possible to generalize its findings.

\section{References}

Aladwani, A. (2002). The development of two tools for measuring the easiness and usefulness of transactional Web sites. European Journal of Information Systems, 11, 223-234.

Araujo, I., \& Araujo, I. (2003). Developing trust in Internet commerce. Proceedings of the 2003 conference of the Centre for Advanced Studies conference on Collaborative Research, Ontario.

Blackwell, C. A., (1995). A good installation guide increases user satisfaction and reduces support costs. Journal of the Society for Technical Communication, 42(1), 56 - 60.

Block, W. (1999). How to create a profit-building web site. Montana Business Quarterly, 37(3), 11. Missoula: Autumn.

Chatterjee, D., Grewal, R., \& Sambamurthy, V. (2002). Shaping up for e-commerce: Institutional enablers of the organizational assimilation of web technologies. MIS Quarterly, 26(2), 65.

Cramer, D. (1998). Fundamental statistics for social research. Step-by-step calculation and computer techniques using SPSS for Windows. London: Routledge.

Dowling, G. R. (1994). Corporate reputations: Strategies for developing the corporate brand. London: Kogan Page

Eighmey, J., \& McCord, L. (1998). Adding value in the information age: Users and gratifications of sites on the World Wide Web. Journal of Business Research, 41, 187-194.

Ellinger, A. E., Lynch, D. F., Andzulis, J. K., \& Smith, R. J. (2003). B-to-B e-commerce: A content analytical assessment of motor carrier websites. Journal of Business Logistics, 24, 199.

Gearson, S. J., \& Gearson, S. M. (1995). A survey of technical writing practitioners and professors: Are we on the same page? $42^{\text {nd }}$ Annual Conference of the Society for Technical Communication, Washington DC, Society for Technical Communication, pp. $44-47$.

Gefen, D., \& Straub, D. (2000). The relative importance of perceived ease of use in IS adoption: A study of e-commerce adoption. Journal of the Association of Information Systems, 1, 1-30.

Giffin, K., (1967). The contribution of studies of source credibility to a theory of interpersonal trust in the communication process. Psychological Bulletin, 68(2), 104-120.

Gray, E. R., \& Balmer M. T. (1998). Managing corporate image and corporate reputation. Long Range Planning, 31(5), 695-702.

Huizingh, E., \& Hoekstra, J. (2002). Why do customers like web sites? Journal of Targeting, Measurements and Analysis for Marketing, 11(4), 350 - 361. 
Karahanna, E., Straub, D., \& Cherveny, N. (1999). Information technology adoption across time: A cross sectional comparison of pre-adoption and post - adoption believes. MIS Quarterly, 23(2), 182 - 213.

Kim, S., Shaw, T., \& Schnider, H. (2003). Web site design benchmarking within industry groups. Internet Research, 13(1), 17.

Kuzic, J., \& Billington, N. (2003). Electronic commerce issues in the Australian manufacturing industry. Proceedings of the 11th European Conference on Information Systems (ECIS 2003), Naples, Italy.

Kuzic, J., Fisher, J., \& Scollary, A. (2002). Electronic commerce benefits, challenges and success factors in the Australian banking and finance industry. Proceedings of the 10th European Conference on Information Systems (ECIS 2002), Gdansk, Poland, University of Gdansk. 160716

Lawrence, M., \& Low, G. (1993). Exploring individual user satisfaction within user-led development. MIS Quarterly, 17(1), $195-208$.

McKnight, D. H., \& Charles, J. K. (2007). Factors and effects of information credibility. Proceedings of the Ninth International Conference on Electronic Commerce. Minneapolis, MN, USA, ACM.

Melius, W., \& Mongezi, M. (2004). Website navigation architectures and their effect on website visibility: A literature survey. Proceedings of the 2004 annual research conference of the South African institute of computer scientists and information technologists on IT research in developing countries. Stellenbosch, Western Cape, South Africa, South African Institute for Computer Scientists and Information Technologists

Nielsen, J. (1999). User interface directions for the web. Communications of the ACM, 42, 65-73.

NOIE (National Office for the Information Economy), (2003). The current state of play: Online participation and activities. Australian Government, Canberra 2003.

Otto, J., Najdawi, M., \& Wagner, W. (2003). An experimental study of web switching. Human Systems Management, 22, 87 - 93.

Prtz. (2008). The digital age public relations corporate image. Retrieved $26^{\text {th }}$ July 2008 , http://prtz.wordpress.com/2008/10/15/the-digital-age-public-relations-corporate-image

Rose, G. M., \& Straub, D. W. (2001). The effects of download time on consumer attitude toward the eService retailer. e-Service Journal, pp. 55 - 76.

Schenkman, B. N., \& Johnsson, F. U. (2000). Aesthetics and performances of web pages. Behaviour and Information Technology, 19(5), $367-377$.

Shim, P., Shin, B., \& Nottingham, L. (2002). Retailer web site influence on customer shopping: An exploratory study on key factors of customer satisfaction. Association for Information Systems, 3, 53-76.

Siegel, S. (1988): Nonparametric statistics for the behavioural sciences. McGraw-Hill.

Silker, C., \& Gurak, L. (1996). Technical communication in cyberspace: Report of a qualitative study. Journal of the Society for Technical Communication, 43, 357-368.

Sternberg, D. (2002). Seven steps to e-health services. Marketing Health Services, 22(2), 44.

Tilson, R., Dong, J., Martin, S., \& Kieke, E. (1998). Factors and principles affecting the usability of four ecommerce sites. Presented at 4th Conference on Human Factors and the Web, Basking Ridge, NJ USA.

Tsalikis, J., Ortiz-Buonafina, M., \& LaTour, M. (1992). The role of accent on the credibility and effectiveness of the international business person: The case Of Guatemala. International Marketing Review, 9(4), 57-73.

Vredenburg, K. (2003). Building ease of use into the IBM user experience. IBM Systems Journal. Armonk, $42(4), 517$. 
Yang, X., Ahmed, Z. U. Ghingold, M., Boon, G. S., Mei, T. S., \& Hwa, L. L. (2003). Consumer preferences for commercial web site design: An Asia-Pacific perspective. The Journal of Consumer Marketing, 20, 10-27.

Zhang, P., \& vonDran, G. M. (2000). Satisfiers and dissatisfiers: A two-factor model for website design and evaluation. Journal of the American Society for Information Science, 51, 1253-1268.

Zhang, P., \& vonDran, G. M. (2002). User expectations and rankings of quality factors in different web site domains. International Journal of Electronic Commerce, 6, 9 - 33.

\section{Biographies}

Dr. Joze Kuzic currently holds the position of the Director of Master of Business (Information Technology Management) at Monash University, Melbourne, Australia. His research interests include Information Systems, E-business, Project Management, and Applied Statistics. Dr. Kuzic has published more than 40 journal, conference papers, and book chapters.

Mr. George Giannatos is a recent MBA Graduate from Monash University during his MBA he has researched and studied E-business in a variety of industries including publishing and telecommunications in Australia. His research focused on challenges, critical success factors and benefits of ebusiness in the e-publishing and telecommunications industry through Technology, Managerial, Business and Other issues.

Ms. Tanja Vignjevic currently studies Postgraduate Diploma of Psychology at Monash University, Melbourne, Australia. Tanja has graduated double degree in Business Management and Marketing at Monash University. Subsequently, she completed a Graduate Diploma of Psychology at the University of Melbourne in 2009. 